\title{
SVRCHNOKŘÍDOVÁ FAUNA (FORAMINIFERA, BIVALVIA) PODSLEZSKÉ JEDNOTKY Z POTOKA KOPYTNÁ V BYSTŘICI NAD OLŠÍ
}

\author{
Late Cretaceous fauna (Foraminifera, Bivalvia) of the Subsilesian Unit from Kopytná stream \\ in Bystřice nad Olší
}

Miroslav Bubík

Česká geologická služba, Leitnerova 22, 65869 Brno; e-mail:miroslav.bubik@geology.cz

(26-11 Jablunkov)

Key words: Subsilesian Unit, Western Carpathians, Cretaceous, palaeontology, Foraminifera, Bivalvia

\begin{abstract}
Recently, Late Cretaceous strata ranging from the Cenomanian to the late Maastrichtian were found in the Subsilesian Unit of Moravian Carpathians. The stratigraphic assignment is based upon planktonic and benthic foraminifer biostratigraphy. Planktonic foraminifer markers: Marginotruncana pseudolinneiana Pess., Globotruncanella petaloidea (Gand.), Laeviheterohelix dentata (Sten.), Rugoglobigerina pennyi (Brön.) and benthic foraminifer markers: Plectorecurvoides irregularis Geroch, Bulbobaculites problematicus (Neagu), Uvigerinammina jankoi Majzon, Conotrochammina sp. etc. are briefly discussed and figured. In Campanian-Maastrichtian marls also articulated specimens of inoceramid bivalves Platyceramus sp. indeterminable to specific level were found. They are related to giant inoceramids known from the Coniacian-Campanian of the Euramerican biogeographical region and North Pacific Province. Folded inoceramid valves evidences slumping of sediment during the early diagenesis, prior to formation of carbonate concretions that include the shells. Both lithology and composition of foraminifer assemblages show trend from eutrophic black clays of the Cenomanian, through greenish silty clays of the Turonian-Coniacian, towards greygreen mottled and more oligotrophic variegated marls and clays of the Campanian-Maastrichtian. Cenomanian taphocoenosis consists of agglutinated taxa dominated by Rhizammina, Hyperammina, Kalamopsis and Adercotryma. Calcareous benthic foraminifers are extremely rare, planktonics are missing. Benthic foraminifer density (specimens per $1 \mathrm{~g}$ of rock) is about 9. Turonian-Coniacian taphocoenosis contains, besides agglutinated taxa, also some calcareous taxa including few planktonics. Campanian-Maastrichtian taphocoenoses comprise agglutinated and calcareous benthics indicating bathyal habitat (Marssonella, Spiroplectammina, Recurvoides, Gyroidinoides). Benthic foraminifer density reaches the value 643. At the same time the planktonic foraminifers represent $94 \%$ of taphocoenosis.
\end{abstract}

Úvod

V posledních letech byly dokumentovány výchozy podslezské jednotky v korytě potoka Kopytná u Bystřice nad Olší v s. části Jablunkovské brázdy. K nejdůležitějším výsledkům patří nález mikropaleontologicky datované svrchní křídy v podslezské jednotce, kterou lze srovnávat s węgloweckým souvrstvím polských Karpat (Bubík, $\mathrm{v}$ tisku). V Kopytné byl doložen turon-coniac ve facii zelených jílovců odlišné od frýdeckého souvrství. Cenoman (černé jíly) byl v podslezské jednotce u nás objeven poprvé. Tato zjištění mění dosavadní představy, že nejstarší částí podslezské jednotky na Moravě je frýdecké souvrství (turon-paleocén). Předložená práce přináší charakteristiku křídové fauny (foraminifer a inoceramidů) a popis význačných druhů.

\section{Metodika}

Výchozy v potoce Kopytná byly dokumentovány v letech 2013 a 2014, v úseku $950 \mathrm{~m}$ až $1,8 \mathrm{~km}$ od ústí do řeky Olše (obr. 1). Popis výchozů a GPS souřadnice jsou obsaženy v jiné práci (Bubík, v tisku). Mikropaleontologické vzorky byly zpracovány v laboratoři ČGS s použitím standardních metod (plavení na sítu $0,063 \mathrm{~mm}$ ). Biostratigrafická interpretace planktonických foraminifer se opírá o manuál Petrizza et al. (2011), u aglutinovaných foraminifer převážně vychází z práce Gerocha - Nowaka (1984). Fotodokumentace foraminifer byla pořízena na mikroskopu Nikon SMZ1500 vybaveném kamerou

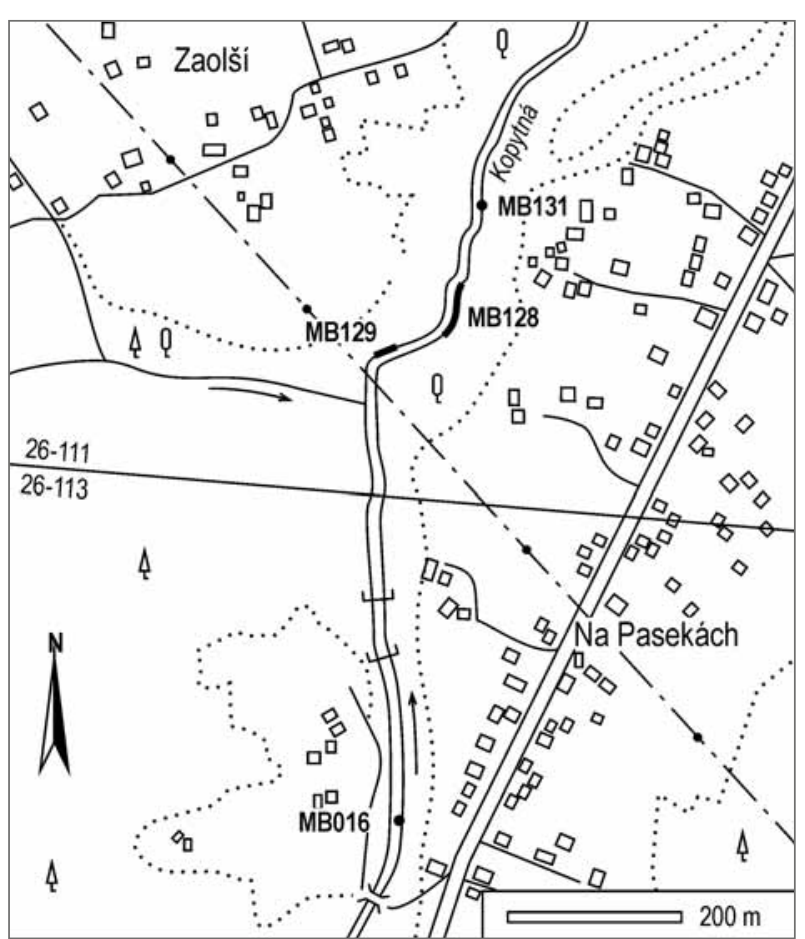

Obr. 1: Situační mapa výchozů kř́idových sedimentů podslezské jednotky v potoce Kopytná.

Fig. 1: Situation map of outcrops of Cretaceous strata of the Subsilesian Unit in Kopytná Stream. 
Tab. 1: Distribuce bentických foraminifer v křídových členech podslezské jednotky v potoce Kopytná. A - hojný; F - častý; x - př́itomen; cf - nejisté určení.

Tab. 1: Distribution of benthic foraminifers in Cretaceous strata of the Subsilesian Unit in Kopytná Stream. A - abundant; F - frequent; $\mathrm{x}$ - present; $\mathrm{cf}$ - uncertain identification.

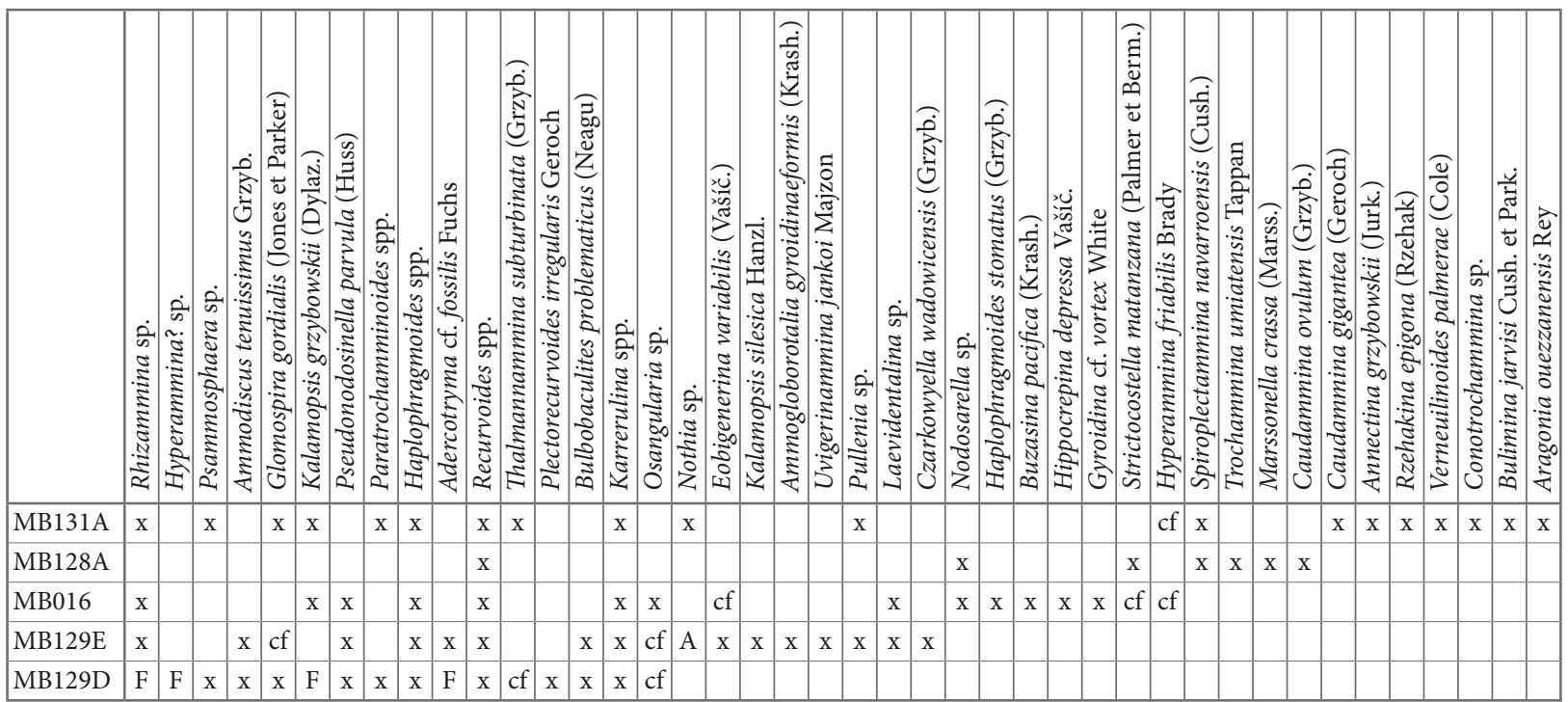

ProgResCT3 a upravena pomocí softvéru NIS-Elements. Fosilní materiál je uložen v rámci hmotné dokumentace ČGS v Brně.

\section{Výsledky}

Černé nevápnité jíly (vzorek MB129D) cenomanského stáří obsahovaly společenstvo aglutinovaných foraminifer s dominancí zástupců rodů Rhizammina, Hyperammina, Kalamopsis a Adercotryma (tab. 1), které spolu s hojnými křemitými jádry radiolarií ukazují na eutrofní podmínky. Vápnité bentické foraminifery jsou ojedinělé, planktonické zcela chybí. Denzita bentických foraminifer je 9 (počet jedinců $\mathrm{v} 1 \mathrm{~g}$ horniny). Cenomanské stáří dokládá spoluvýskyt druhů Plectorecurvoides irregularis Geroch a Bulbobaculites problematicus (Neagu).

Zelenošedé prachovité jíly (vzorek MB129E) patři k turon-coniacu na základě výskytu Marginotruncana pseudolinneiana Pess., Uvigerinammina jankoi Majzon a Bulbobaculites problematicus. Ve společenstvu bentosu převažují aglutinované druhy s dominancí Nothia sp. Bentos vysoce převažuje nad planktonem. Campan-maastricht byl doložen ve světle šedých skvrnitých slínech (vzorek MB128A) a šedých vápnitých jílech (vzorek MB016) na základě výskytu planktonických foraminifer (tab. 2). Foraminiferový bentos zastoupený vápnitými i aglutinovanými taxony (Marssonella, Spiroplectammina, Recurvoides, Gyroidinoides) dokládá hloubky batyálu. Rovněž inoceramidní mlži Platyceramus sp. zasahovali svým výskytem do hloubek horního batyálu, takže jejich výskyt v takto hlubokých faciích nemusí znamenat jejich redepozici (viz Kauffman et al.
2007). Denzita bentosních foraminifer dosahuje hodnot až 643 jedinců na $1 \mathrm{~g}$ horniny. Přitom plankton představuje $94 \%$ foraminiferové fauny (MB128A).

Do vyššího maastrichtu lze pravděpodobně zařadit tektonicky drcené zelenavě šedé, rudohnědošedě smouhované vápnité jíly (vzorek MB131A) na základě výskytu campan-maastrichtského planktonu (tab. 2) a ojedinělé Conotrochammina sp., jejíž výskyt je znám od svrchního maastrichtu. Ve vzorku byly vzácně zjištěny paleogénní druhy Subbotina sp., Acarinina soldadoensis (Brön.) a Bulimina jarvisi Cush. et Park. (tab. 1,2), které lze považovat za kontaminaci způsobenou tektonickým porušením polohy jílů.
Tab. 2: Distribuce planktonických foraminifer v kř́idových členech podslezské jednotky v potoce Kopytná v Bystřici nad Olší.

Tab. 2: Distribution of planktonic foraminifers in Cretaceous strata of the Subsilesian Unit in Kopytná Stream in Bystřice nad Olší.

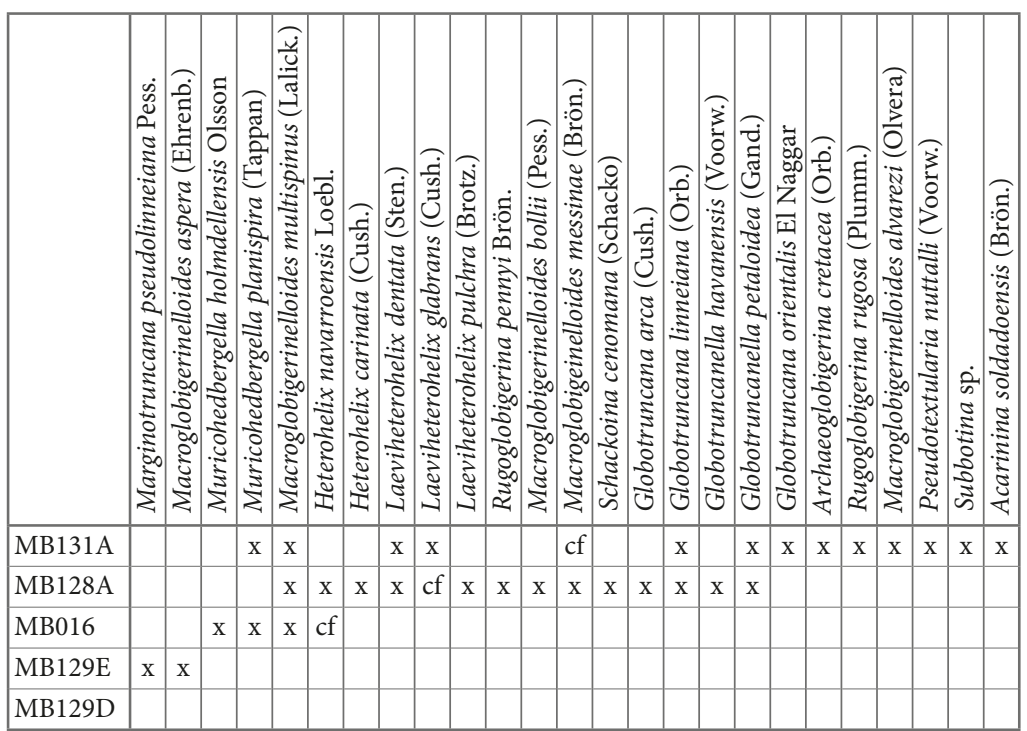




\section{Systematická část}

\section{Foraminifera}

Adercotryma cf. fossilis Fuchs, 1971

Obr. 2C

cf. 1971 Adercotryma fossilis: Fuchs, p. 9, pl. 2, fig. 14.

Fuchs (1971) popsal A. fossilis z barremu Východních Alp. Další zprávy o stratigrafickém a geografickém rozšíření zatím chybí. Vztah druhu k žijícím zástupcům rodu je nejasný, protože nejstarší problematičtí zástupci jsou známi z campanu (Wightman-Kuhnt 1992). Forma z Kopytné se od $A$. fossilis liší pouze volnějším vinutím, což se projevuje více laločnatou periferií schránky. Hojně se vyskytuje v tmavých cenomanských jílech, vzácněji $\mathrm{v}$ zeleném jílovci turon-coniacu.

Ammogloborotalia gyroidinaeformis (Krasheninnikov, 1974)

Obr. $2 \mathrm{G}$

1974 Trochammina gyroidinaeformis: Krasheninnikov, p. 641, pl. 5, figs 7-9.

Druh byl poprvé popsán ze svrchní křídy Indického oceánu (DSDP 261), v abysálních faciích je ale patrně kosmopolitní. Jedinci z Kopytné se vyznačují velmi malými rozměry. V karpatském flyši byl zaznamenán od turonu po campan-maastricht (Bubík 1995).

\section{Annectina grzybowskii Jurkiewicz, 1960}

Obr. 2I

1960 Glomospira grzybowskii: Jurkiewicz, p. 342, pl. 38, figs 7, 10, 11 .

1995 Glomospirella grzybowskii: Bubík, p. 81, pl. 9, fig. 12.

V Kopytné byl tento druh zjištěn v maastrichtských pestrých jílech. V karpatském flyši je rozšířen od campanu do konce paleocénu.

Bulbobaculites problematicus Neagu, 1962

Obr. 2A, B

1962 Ammobaculites agglutinans problematicus: Neagu, p. 61, pl. 2, figs 22-24.

B. problematicus byl poprvé popsán ze svrchní křídy rumunských Karpat. Jeho rozšíŕení je prakticky kosmopolitní. Je indexovým druhem v rámci zonace Gerocha-Nowaka (1984). Stratigrafický rozsah v karpatském flyši je vyšší cenoman až coniac (l. c.).

\section{Caudammina gigantea Geroch, 1960}

Obr. $2 \mathrm{~S}$

1960 Hormosina ovulum gigantea: Geroch, p. 43, pl. 2, figs. 18, 19.

Kosmopolitně rozšířený druh popsaný původně z karpatského flyše je indexovým druhem zóny s rozsahem vyšší campan-maastricht v zonaci Gerocha-Nowaka (1984). Stratigrafický rozsah bývá uváděn obvykle od středního campanu do konce maastrichtu, ale ojedinělé výskyty jsou popisovány už od santonu (Olszewska 1997) nebo coniacu (Bubík et al. 2008).

\section{Conotrochammina sp.}

Obr. $2 \mathrm{H}$

1995 Trochammina? sp. 4: Bubík, p. 88., pl. 7, fig. 21, pl. 14, fig. 3 .

1999 „Trochammina“ sp. 4: Bubík et al., p. 36., fig. 4i, cf. $4 \mathrm{~h}$.

Tento druh popsaný poprvé z karpatského flyše na Moravě byl provizorně zařazen k rodu Trochammina, ale pravděpodobně se jedná o nový druh rodu Conotrochammina. Vyskytuje se vzácně v paleocénu, ojediněle i ve svrchním maastrichtu (Bubík et al. 1999).

Czarkowyella wadowicensis Grzybowski, 1896

Obr. $2 \mathrm{~K}, \mathrm{~L}$

1896 Pleurostomella wadowicensis: Grzybowski, p. 290, pl. 10, fig. 1.

1981 Pleurostomella wadowicensis: Liszka a Liszkowa, p. 183 , pl. 4 , fig. 7 .

Od rodu Pleurostomella se Czarkowyella liší triseriálně uspořádanými počátečními komůrkami. Tento znak je na robustních hladkých schránkách často obtížně pozorovatelný, takže publikované zprávy o výskytu zástupců jsou nečetné. Ze tři známých druhů se jedinci z turon-coniacu z Kopytné nejvíce blíží druhu C. wadowicensis, popsanému z campanských červených slínů podslezské jednotky v Polsku. C. torta (Cush.) je výrazně robustnější a má kratší komůrky, C. czarkowyensis Gawor-Biedowa má vkleslé švy, a to i ve starší části schránky. V materiálu z Kopytné byla vedle mikrosférické generace s triseriálním počátkem (obr. $2 \mathrm{~K}$ ) pozorována i megalosférická forma s výrazně větším prolokulem a kompletně biseriálním uspořádáním komůrek (obr. 2L). Śírka a tvar poslední komůrky studovaných jedinců je značně variabilní.

\section{Eobigenerina variabilis Vašíček, 1947}

Obr. $2 \mathrm{~F}$

1947 Bigenerina variabilis: Vašíček, p. 246, pl. 1, figs 10-12.

2011 Eobigenerina variabilis: Cetean et al., p. 22, pl. 1, figs 1-12.

Geroch-Nowak (1984) použili tento druh jako index barrem-aptské zóny v jejich zonaci. Jak ukázala pozdější revize (Cetean et al. 2011), jejich taxonomický koncept je však od původního Vašíčkova druhu odlišný druhově i rodově. Nověji se stratigrafický rozsah E. variabilis uvádí od tithonu do eocénu.

Globotruncanella petaloidea Gandolfi, 1955

Obr. $2 \mathrm{~T}$

1955 Globotruncana (Rugoglobigerina) petaloidea petaloidea: Gandolfi, p. 52, pl. 3, fig. 13.

Jedinci z Kopytné mají 4 až 4,5 komůrek v posledním závitu, což je pro tento druh charakteristické. Stratigrafický rozsah se uvádí od svrchního campanu do konce maastrichtu (Petrizzo et al. 2011). 


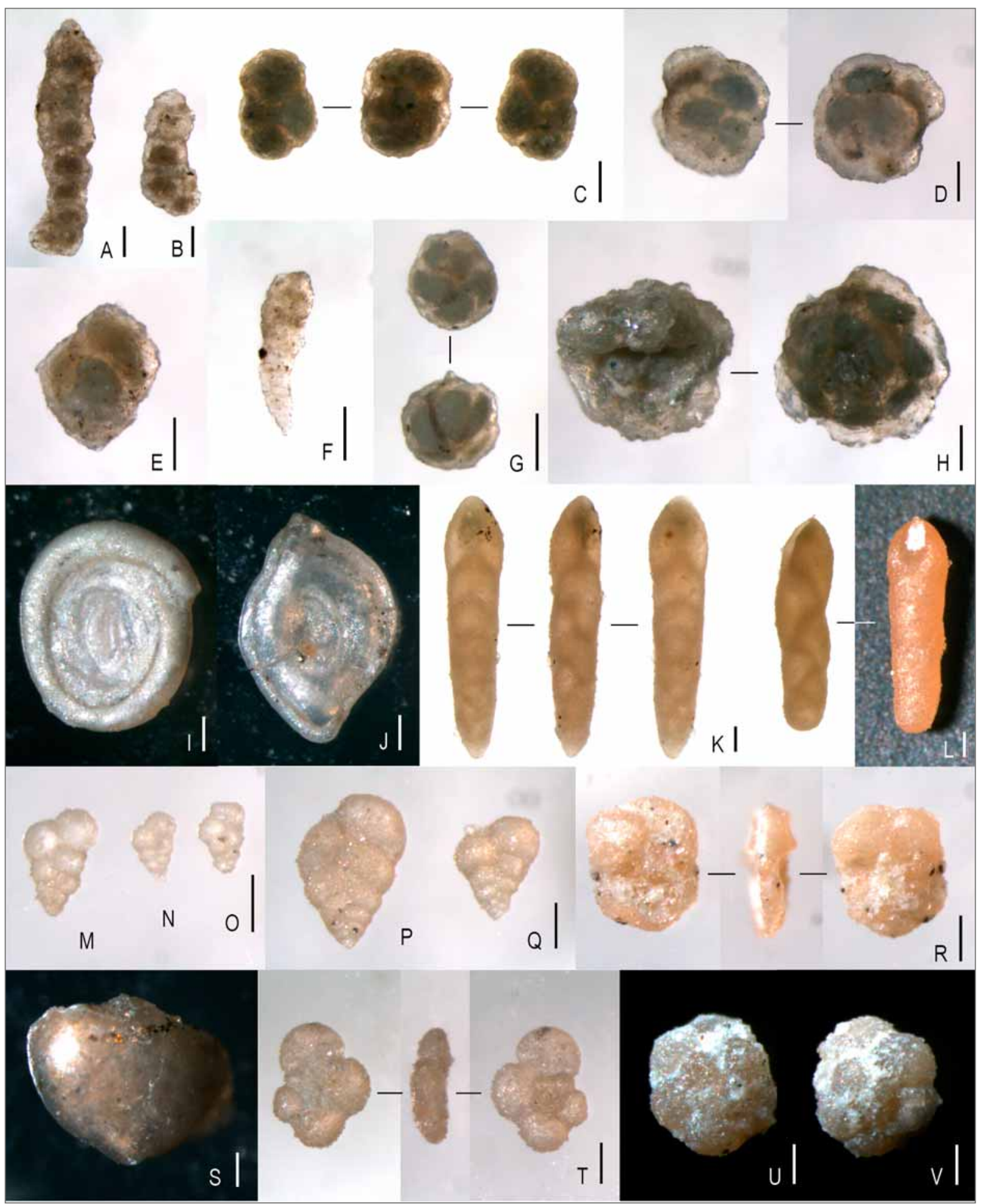

Obr. 2: Význačné druhy foraminifer z křídy podslezské jednotky v Kopytné: A, B - Bulbobaculites problematicus (Neagu), MB129D; C - Adercotryma cf. fossilis Fuchs, MB129D; D - Plectorecurvoides irregularis Geroch, MB129D; E - Uvigerinammina jankoi Majzon, MB129E; F - Eobigenerina variabilis (Vašíček), MB129E; G - Ammogloborotalia gyroidinaeformis (Krash.), H - Conotrochammina sp., MB131A; I - Annectina grzybowskii (Jurk.), MB131A; J - Rzehakina epigona (Rzehak), MB131A; K, L - Czarkowyella wadowicensis (Grzyb.), MB129E; M, N, O - Heterohelix navarroensis Loeblich, MB128A; P, Q - Laeviheterohelix dentata (Sten.), MB128A; R - Marginotruncana pseudolinneiana Pess., MB129E; S - Caudammina gigantea (Geroch), MB131A; T - Globotruncanella petaloidea (Gand.), MB128A; U, V - Rugoglobigerina pennyi Brön., MB128A. Délka měřítka $=0,1 \mathrm{~mm}$.

Fig. 2: Important foraminifers from the Cretaceous of the Subsilesian Unit in Kopytná: A, B - Bulbobaculites problematicus (Neagu), MB129D; C - Adercotryma cf. fossilis Fuchs, MB129D; D - Plectorecurvoides irregularis Geroch, MB129D; E - Uvigerinammina jankoi Majzon, MB129E; F - Eobigenerina variabilis (Vašíček), MB129E; G - Ammogloborotalia gyroidinaeformis (Krash.), H - Conotrochammina sp., MB131A; I - Annectina grzybowskii (Jurk.), MB131A; J - Rzehakina epigona (Rzehak), MB131A; K, L - Czarkowyella wadowicensis (Grzyb.), MB129E; M, N, O - Heterohelix navarroensis Loeblich, MB128A; P, Q - Laeviheterohelix dentata (Sten.), MB128A; R - Marginotruncana pseudolinneiana Pess., MB129E; S - Caudammina gigantea (Geroch), MB131A; T - Globotruncanella petaloidea (Gand.), MB128A; U, V - Rugoglobigerina pennyi Brön., MB128A. Scale bar $=0.1 \mathrm{~mm}$. 
Heterohelix navarroensis Loeblich, 1951

Obr. 2M-O

1951 Heterohelix navarroensis: Loeblich, p. 107, pl. 12, figs $1-3$, txt-fig. 2 .

Jedná se o drobný druh. Vzhledem k rekrystalizaci materiálu z Kopytné nelze vyloučit záměnu s juvenilními jedinci jiných druhů jako H. globulosa (Ehrenberg). Stratigrafický rozsah se uvádí od středního campanu do konce maastrichtu (Petrizzo et al. 2011).

\section{Laeviheterohelix dentata Stenestad, 1968}

Obr. 2P, Q

1968 Heterohelix dentata: Stenestad, p. 67, pl. 1, figs 3-6, 8-9, 11, pl. 2, figs. 1-3.

Stratigrafický rozsah se uvádí od svrchního campanu do konce maastrichtu Petrizzo et al. 2011.
Marginotruncana pseudolinneiana Pessagno, 1967

Obr. 2R

1967 Marginotruncana pseudolinneiana: Pessagno, p. 193, pl. 65, figs 24-27, pl. 76, figs $1-3$.

Stratigrafický rozsah se uvádí od středního turonu do nejnižšího campanu (Petrizzo et al. 2011).

\section{Plectorecurvoides irregularis Geroch, 1962}

Obr. 2D

1962 Plectorecurvoides irregularis: Geroch, p. 297, pl. 3, figs. 9, 10.

Druh poprvé popsaný $\mathrm{z}$ karpatského flyše v Polsku je rozšířen v hlubokomořských faciích od barremu do nejvyššího cenomanu.

\section{Recurvoides spp.}

Vedle řady blíže neurčitelných zástupců rodu Recurvoides byly ojediněle identifikovány následující druhy: $\mathrm{v}$ jílech cenomanu-coniacu Recurvoides cf. imperfectus (Hanzl.) a R. recurvoidiformis (Neagu et Toc.); ve vápnitých

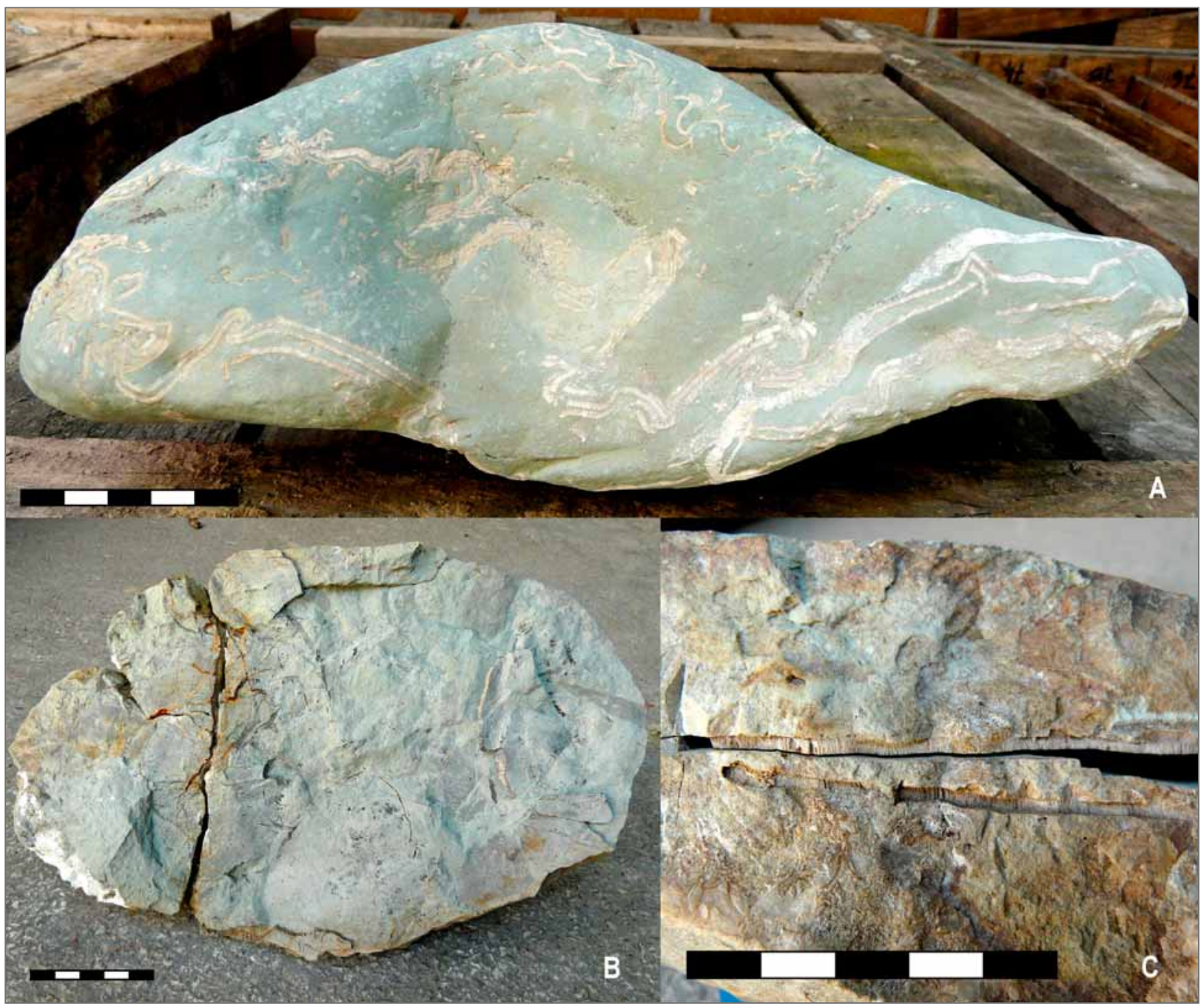

Obr. 3: Inoceramidní mlži Platyceramus sp. z campan-maastrichtu podslezské jednotky v Kopytné: A - deformovaní artikulovaní jedinci v konkreci slínovce z náplavu Kopytné; B - nekompletní miska v rozštíplé konkreci, MB128; C - tentýž kus, detail příčného lomu oběma miskami. Měŕítko $=5 \mathrm{~cm}$.

Fig. 3: Inoceramid bivalve Platyceramus sp. from the Campanian-Maastrichtian of the Subsilesian Unit in Kopytná: A - deformed articulated specimens in marlstone concretion from Kopytná riverbed sediments; B - incomplete valve in splitted concretion, MB128; $\mathrm{C}$ - the same specimen, detail of the cross section through both valves. Scale bar $=5 \mathrm{~cm}$. 
jílovcích campan-maastrichtu $R$. minimus Neagu et Platon, $R$. retroseptus (Grzybowski) a $R$. cf. anormis Mjatl. Rod Recurvoides představuje charakteristickou a často zásadní složku foraminiferových biofacií batyálu a abysálu.

\section{Rzehakina epigona Rzehak, 1895}

Obr. 2J

1895 Silicina epigona: Rzehak, p. 214, pl. 6, fig 1.

Charakteristický druh turbiditních facií karpatského flyše se v Karpatech vyskytuje od campanu do konce paleocénu.

Rugoglobigerina pennyi Brönnimann, 1952

Obr. 2U, V

1952 Rugoglobigerina (Rugoglobigerina) rugosa pennyi: Brönnimann, p. 34, pl. 4, figs 1-3.

Někteří jedinci z Kopytné mají jen 5 komůrek v posledním závitu, hrubá ornamentace a vyšší spira je nicméně řadí $\mathrm{k} R$. pennyi spíše než $\mathrm{k} R$. rugosa (Plummer). Stratigrafický rozsah se uvádí od svrchního campanu do konce maastrichtu (Petrizzo et al. 2011).

Uvigerinammina jankoi Majzon, 1943

Obr. 2E

1943 Uvigerinammina jankoi: Majzon, p. 158, pl. 2 fig. 15.

Stratigraficky významný druh byl poprvé popsán z krrídy bradlového pásma na Zakarpatské Ukrajině. Vyskytuje se kosmopolitně od turonu (místy od cenomanu) do středního campanu. Geroch - Nowak (1984) jej použili jako indexový druh zóny o rozsahu turon-santon.

\section{Bivalvia}

Platyceramus sp.

\section{Obr. 3A-C}

Světle šedé skvrnité jílovce z lokality MB128 obsahovaly čočkovité vápnité konkrece uzavírající misky inoceramů s charakteristickou prizmatickou stavbou viditelnou na lomu (obr. 3C). Misky jsou velké, ale silné jen kolem $2 \mathrm{~mm}$. Jsou ploché a hladké, bez náznaku koncentrických vln a prrírůstkových linií. Obvykle jde o artikulované misky, pravděpodobně tedy nepřemístěné a snad přímo v životní pozici. Misky jsou zachované pouze uvnitř konkrecí a jejich pokračování do okolního jílovce nebylo pozorováno. Nálezy mají proto často charakter fragmentu přes celý průměr konkrece, ale bez okrajů a vrcholu (obr. 3B). Původní velikost misky se dá odhadovat na $30 \mathrm{až} 50 \mathrm{~cm}$. V konkreci nalezené volně v korytě Kopytné poblíž lokality bylo zjištěno nahromadění nejméně 7 artikulovaných jedinců (obr. 3A). Tento nález je zajímavý sedimentologicky, protože dokládá gravitační deformaci dna (podmořský skluz) během rané diageneze, tj. po uložení a kompakci bahna a před vznikem vápnité konkrece. Na plastickém zvrásnění misek mělo patrně podíl tlakové rozpouštění kalcitu.

Velké ploché a hladké typy inoceramů lze nejspíše zařadit do rodu Platyceramus Heinz, rozšířeného od coniacu do maastrichtu (S. Čech, ústní sdělení). Taxonomie na úrovni druhu je komplikovaná a nedořešená. Nekompletní materiál z Kopytné je blíže neurčitelný. Zástupci rodu se vyskytují hojně v euroamerickém regionu a severopacifické provincii. Byli popsáni z šelfových sedimentů a fan delty stárí coniac-santon v gosauské pánvi Východních Alp (Tröger-Summersberger 1994) a z turbiditních facií campanu skolské jednotky (Kotlarczyk et al. 1977). Za zmínku stojí, že zástupci rodu z coniacu až campanu USA dosahují velikosti $1 \mathrm{~m}$, výjimečně až $3 \mathrm{~m}$, čímž se stali největšími mlži, kteří kdy žili na Zemi. Obývali dysoxické prostředí v hloubkách 200-350 m a živili se velmi pravděpodobně chemosymbioticky (Kauffman et al. 2007).

\section{Závěry}

Na základě foraminiferové fauny byly na výchozech podslezské jednotky v oblasti Jablunkovské brázdy doloženy svrchnokřídové pelitické sedimenty v rozsahu cenoman až maastricht. Litologie i obsažená mikrofauna ukazuje na trend od eutrofních černých jílů cenomanu, přes zelené prachovité jíly turon-coniacu, po šedozelené skvrnité a pestré oligotrofnější slíny a jíly campan-maastrichtu. Ve foraminiferové fauně byly zjištěny některé málo známé taxony jako Adercotryma cf. fossilis a Czarkowyella wadowicensis. Tafocenózy foraminifer ukazují na hloubky batyálu. Výskyt artikulovaných inoceramidních mlžů z př́buzenstva obřích druhů rodu Platyceramus lze považovat za autochtonní faunu. Jejich deformace dokládají nestabilitu podmořského svahu v průběhu rané diageneze sedimentů.

\section{Poděkování}

Článek je př́spěvkem $k$ prioritě č. 1 strategického plánu výzkumu ĆGS (Komplexní regionální a hloubkový výzkum litosféry). Autor děkuje S. Čechovi za komentář k nalezené inoceramovéfauně $\mathrm{D}$. Boorové za pečlivé pročtení rukopisu. 


\section{Literatura}

Brönnimann, P. (1952): Globigerinidae from the Upper Cretaceous (Cenomanian-Maestrichtian) of Trinidad, B. W. I. - Bulletins of American Paleontology, 34, 5-71.

Bubík, M. (1995): Cretaceous to Paleogene agglutinated foraminifera of the Bílé Karpaty unit (West Carpathians, Czech Republic). - In: Kaminski, M. A. - Geroch, S. - Gasinski, M. A. (eds): Proceedings of the Fourth International Workshop on Agglutinated Foraminifera, Grzybowski Foundation Special Publication, 3, 71-116.

Bubík, M. (v tisku): Nové poznatky o stratigrafii podslezské jednotky v Jablunkovské brázdě: potok Kopytná. - Zprávy o geologických výzkumech, 2016.

Bubík, M. - Bąk, M. - Švábenická, L. (1999): Biostratigraphy of the Maastrichtian to Paleocene distal flysch sediments of the Rača Unit in the Uzgruň section (Magura Group of Nappes, Czech Republic). - Geologica Carpathica, 50, 1, 33-48.

Bubík, M. - Skupien, P. - Švábenická, L. (2008): Stratigrafie křídových pestrých oceánských vrstev karpatského flyše na Moravě. - Geologické výzkumy na Moravě a ve Slezsku, 14, 46-52.

Cetean, C. - Setoyama, E. - Kaminski, M. A. - Neagu, T. - Bubík, M. - Filipescu, S. - Tyszka, J. (2011): Eobigenerina, a cosmopolitan deep-water agglutinated foraminifer, and remarks on late Paleozoic to Mesozoic species formerly assigned to Pseudobolivina and Bigenerina. - In: Kaminski, M. A. - Filipescu S. (eds.): Proceedings of Eight International Workshop on Agglutinated Foraminifera, Grzybowski Foundation Special Publication, 16, 19-27.

Fuchs, W. (1971): Eine alpine Foraminiferenfauna des tieferen Mittel-Barreme aus den Drusbergschichten vom Ranzenberg bei Hohenems in Vorarlberg. - Abhandlungen der Geologischen Bundesanstalt, 27, 1-49.

Gandolfi, R. (1955): The genus Globotruncana in Northeastern Colombia. - Bulletins of American paleontology, 36, 7-118.

Geroch, S. (1960): Zespoły mikrofauny z kredy i paleogenu serii śląskiej w Beskidzie Śląskim. - Biuletyn (Instytut Geologiczny Warszawa), 153, 7-138.

Geroch, S. (1962): Otwornice z rodzaju Thalmannammina i Plectorecurvoides w dolnej kredzie Karpat fliszowych. - Rocznik Polskiego Towarzystwa Geologicznego, 32, 2, 281-300.

Geroch, S. - Nowak, W. (1984): Proposal of zonation for the Late Tithonian - Eocene, based upon the arenaceous foraminifera from the outer Carpathians, Poland. - In: Oertli, H. (ed.): Benthos '83, 2nd International Symposium on Benthic Foraminifera, Pau (France), April 11-15, 1983: Elf Aquitaine, ESSO REP and TOTAL CFP, 225-239.

Grzybowski, J. (1896): Otwornice czerwonych iłów z Wadowic. - Rozprawy Akademii Umiejętności w Krakowie, Wydział Matematyczno-Przyrodniczy, ser. 2, 30, 261-308.

Jurkiewicz, H. (1960): Otwornice z łupków czarnorzeckich wschodniej częsci jednostki śląskiej. - Rocznik Polskiego Towarzystwa Geologicznego, 30, 3, 333-343.

Kauffman, E. G. - Harries, P. J. - Meyer, C. - Villamil, T. - Arango, C. - Jaecks, G. (2007): Paleoecology of giant Inoceramidae (Platyceramus) on a Santonian (Cretaceous) seafloor in Colorado. - Journal of Paleontology, 81, 1, 64-81.

Kotlarczyk, J. - Mitura, F. - Rajchel, J. (1977): Inoceramus salisburgensis from the Inoceramian Beds near Rybotycze (Polish East Carpathians). - Rocznik Polskiego Towarzystwa Geologicznego, 47, 3, 371-381.

Krasheninnikov, V. A. (1974): Upper Cretaceous benthonic agglutinated foraminifera, Leg 27 of the Deep Sea Drilling Project. In: Veevers, J. J. - Heirtzler, J. R. et al.: Initial Reports of the Deep Sea Drilling Project 27, 631-662.

Liszka, S. - Liszkowa, J. (1981): Revision of J. Grzybowski's paper (1896) „Foraminifera of the red clays from Wadowice”. - Rocznik Polskiego Towarzystwa Geologicznego, 51, 1/2, 153-208.

Loeblich, A. R. (1951): Coiling in the Heterohelicidae. - Contributions from the Cushman Foundation for Foraminiferal Research, 2, 106-110.

Majzon, L. (1943): Beiträge zur Kenntniss einiger Flysch-Schichten des Karpaten-Vorlandes mit Rücksicht auf die Globotruncanen. - A magyar Királyi Földtani Intézet, Évkönyve, 37, 1-170.

Neagu, T. (1962): Studiul foraminiferelor aglutinante din argilele cretacic-superioare de pe Valea Sadova (Cîmpulung Moldovenesc) si basinul superior al Vaii Buzaului. - Studii Cecetari Geologie, Academia Republicii Populare Romane, Sectia de Geologie si Geografie si Istitutul de Geologie si Geografie, 7, 45-81.

Olszewska, B. (1997): Foraminiferal biostratigraphy of the Polish Outer Carpathians: a record of basin geohistory. - Annales Societatis Geologorum Poloniae, 67, 325-337.

Pessagno, E. A. (1967): Upper Cretaceous planktonic foraminifera from the West Coastal Plain. - Palaeontographia Americana, $5,259-441$.

Petrizzo, M. R. - Premoli Silva, I. - Verga, D. (2011): Practical Manual of Cretaceous Planktonic Foraminifera. - International School on Planktonic Foraminifera, 3rd Course 2004. New Editing 2011. - Universities of Perugia and Milan, 1-265.

Rzehak, A. (1895): Ueber einige merkwürdige Foraminiferen aus dem österreichischen Tertiär. -Annalen des Naturhistorischen Museums in Wien, 10, 213-230.

Stenestad, E. (1968): Three new species of Heterohelix Ehrenberg from the upper Senonian of Denmark. - Meddelelser fra Dansk Geologisk Forening, 18, 64-70.

Tröger, K. A. - Summersberger, H. (1994): Coniacian and Santonian inoceramid bivalves from the Gosau-Goup (Cretaceous, Austria) and their biostratigraphic and palaeogeographic significance. - Annalen des Naturhistorischen Museums in Wien, 96A, 161-197.

Vašíček, M. (1947): Poznámky k mikrobiostratigrafii magurského flyše na Moravě. - Věstník Státního Geologického Ústavu Československé Republiky, 22, 235-256.

Wightman, W. G. - Kuhnt, W. (1992): Biostratigraphy and paleoecology of Late Cretaceous abyssal agglutinated foraminifers from the western Pacific Ocean (DSDP Holes 196A and 198A and ODP Holes 800A and 801A). - In: Larson, R. L. - Lancelot, Y. et al. (eds): Proceedings of the Ocean Drilling Program, 129, 247-264. 